Scholarship Repository

University of Minnesota Law School

Articles

Faculty Scholarship

2009

\title{
Norval Morris's Contributions to Sentencing Structures, Theory, and Practice
}

Richard Frase

University of Minnesota Law School, frase001@umn.edu

Follow this and additional works at: https://scholarship.law.umn.edu/faculty_articles

Part of the Law Commons

\section{Recommended Citation}

Richard Frase, Norval Morris's Contributions to Sentencing Structures, Theory, and Practice, 21 FED. SENTENCING R. 254 (2009), available at https://scholarship.law.umn.edu/faculty_articles/523.

This Article is brought to you for free and open access by the University of Minnesota Law School. It has been accepted for inclusion in the Faculty Scholarship collection by an authorized administrator of the Scholarship Repository. For more information, please contact lenzx009@umn.edu. 


\section{Norval Morris's Contributions to Sentencing Structures, Theory, and Practice}

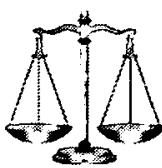

\section{RICHARD S.} FRASE*

Benjamin N. Berger

Professor of

Criminal Law,

University of

Minnesota Law

School
As a disciple and former student of Norval Morris, it is a great honor to be asked to assess his contributions to sentencing. As the title of this essay suggests, Morris's ideas encompassed sentencing structures, theory (sentencing purposes), and practice (sentencing outcomes). In all three of these domains, the key to creating a just, workable, and enduring sentencing system is balance, and balance is the essence of Morris's approach.

Morris's proposed sentencing structures allow for shared policy-making and case-level authority between the legislature, executive and administrative agencies (corrections departments and officials, sentencing commissions, parole boards), trial courts, appellate courts, prosecutors, and defenders. With respect to purposes, modern sentencing systems must accommodate a wide variety of important but often conflicting goals, both retributive (desert-based) and nonretributive. The latter include not only purposes that seek to prevent crimethrough deterrence, moral teaching (norm-definition and reinforcement), incapacitation, and/or rehabilitation and reintegration-but also other purposes such as restorative and community-oriented justice that have valuable effects beyond crime control. Morris's hybrid theory provides substantial scope for the pursuit of all of these purposes.

Another critical dimension, related to both structure and purposes, reflects the eternal conflict between rule and discretion. There is great value in a system in which similarly situated offenders receive similar sentences (uniformity or equality goals), and where sentencing outcomes are reasonably predictable (deterrent and resource-management goals). But discretion and flexibility are also valuable, allowing courts and other officials to tailor the specific sentence to the infinitely variable and unpre. dictable facts and circumstances of individual cases. Morris sought to craft sentencing procedures that strike a balance between rule and discretion. Finally, with respect to sentencing outcomes, Morris sought a better mix of custodial and noncustodial alternatives, and his overall principle of sentencing parsimony recognized that the need to protect and respect the rights of crime victims and the public must be balanced against the costs and destructive effects of punishment.
The first part of this essay summarizes Morris's writings on sentencing, with particular emphasis on his theory of limiting retributivism. The second part moves from theory to practice and describes how Morris's theory was successfully implemented under the Minnesota Sentencing Guidelines-without, as far as I can tell, any key policy maker ever expressly citing or crediting Morris. However, several possible indirect Morris influences on the Guidelines can be identified. The concluding section of the essay stresses a critically important feature of the Minnesota Guidelines that has no counterpart in Morris's theory (resource-impact assessments); notes some important ways in which Minnesota did not go as far as Morris would have liked; and considers the future of the MorrisMinnesota model.

\section{Summary of Morris's Writings on Sentencing} Over a period of more than forty years, Norval Morris addressed all of the most important issues of sentencing policy and practice. ${ }^{1}$ His first books and articles, published in the early 1950s, recognized the problems of sentencing disparity, the unresolved conflicts between sentencing purposes, and the need for sentencing theory and policy to be informed by sentencing practice, building on the accumulated wisdom of the past. Morris's earliest writings also argued that judges should give reasons for their sentences, subject to appellate review-two procedural reforms which would later become important elements of many sentencing guidelines systems. Over the next two decades, Morris's writings developed another major theme-his attack on the excesses of discretion and severity resulting from traditional, rehabilitation-centered indeterminate sentencing regimes. To prevent these excesses, he argued that retributive values - the offender's just deserts-must establish a firm upper limit on sentencing severity. Morris further questioned traditional parole release discretion because he doubted the effectiveness of in-prison treatment programs and the ability of parole boards to accurately assess progress toward rehabilitation. He also continued to argue for noncustodial sentencing alternatives and for shorter, and nonmandatory, custody terms.

Morris's theory of Limiting Retributivism was implicit in the early writings summarized above, but he provided a

Federal Sentencing Reporter, Vol. 21, No. 4, pp. 254-260, ISSN 1053-9867 electronic ISSN 1533-8363 (C) 2009 Vera Institute of Justice. All rights reserved. Please direct requests for permission to photocopy or reproduce article content through the University of Califormia Press's Rights and Permissions website, http://www.ucpressjournals.com/reprintInfo.asp. DOI: 10.1525/fsr.2009.21.4.254. 
more comprehensive statement of the theory in his seminal book, The Future of Imprisonment, published in 1974. I was a recent law school graduate at the time, and reading Morris's book was like Revelation-finally, sentencing theory made sense! Judging by the influence the book has had, I am not the only one who had that reaction.

Here are the key elements of his theory as stated in his 1974 book and in later writings: ${ }^{2}$

1. Sentences must not be undeserved, but desert is imprecise-Morris argued that in any given case there will be widespread agreement that certain penalties are clearly undeserved (either excessively severe or excessively lenient), but there may be little political and philosophical consensus on the offender's precise deserts. Morris also recognized the goal of equality in sentencing. But as with desert, he saw this not as a precise imperative but only a general guiding principle- - "like cases should be treated alike ... unless there are other substantial utilitarian reasons to the contrary"; unequal penalties can still be "just." 3 Morris's lower desert limits appeared to be flexible and based in part on utilitarian, standard-setting considerations (so as not to "depreciate the seriousness" of the crime ${ }^{4}$.

2. Within the range of deserved (or not undeserved) penalties, Morris would allow all other traditional sentencing purposes to be considered, especially general deterrence, subject to an overall, limiting principle of humaneness and economy which he called "parsimony" - the sentence imposed should be no more severe than necessary to achieve these other purposes. In practice, this means that judges should start at the low end of the range of deserved penalties and only increase the sentence as needed to achieve non-desert-based sentencing purposes.

3. Morris maintained that clinical or other highly individualized predictions of dangerousness are inherently unreliable and overinclusive; therefore, such predictions should rarely be a basis to impose or prolong a prison term. He was willing to abolish parole release discretion but stipulated that if it were retained, the timing of release should be based on actuarial predictions of risk; moreover, such predictions and a proposed initial parole date should be settled within a few weeks of the offender's arrival in prison. In any case, Morris would retain a parolelike period of conditional release. However, it should be a fixed period rather than the remaining prison term; the latter, more traditional approach tends to give the shortest supervision terms to the highest-risk (most parole-delayed) offenders, and vice versa.

4. Morris continued to attack the "rehabilitative ideal" of compelled in-prison treatment tied to discretionary parole release. He argued that all prison treatment programs should be voluntary and that a prisoner's apparent progress in treatment should not affect the timing of his release. Morris felt that involuntary treatment programs wasted resources on unamenable offenders and encouraged them to cynically "act" rehabilitated. With or without treatment, he believed that in-prison behavior and attitudes provide no sound basis for predicting the offender's postrelease risk of reoffending. However, Morris did recognize the need to maintain prison order by granting good-conduct credits, and he also stipulated that inmates could be required to take part in prescribed treatment programming long enough to see if they might want to continue. And he also strongly supported community-based treatment programs and would allow attendance at such programs to be a condition of probation or postprison release.

5. Although he rejected highly discretionary, individualized assessments of dangerousness and need for treatment, Morris would allow enhanced sentences based on the offender's prior conviction record. He viewed such enhancements as deserved but also as a means of incapacitating higher-risk offendersprior offending is the best predictor of future offending but, as with parole release, such predictions should be made on an actuarial rather than an individualized basis.

6. As noted, Morris believed that sentences should be subject to appellate review, in order to improve sentencing consistency and ensure that desert and parsimony limits are respected. Morris also believed that appellate decisions would, through the timehonored, common-law process, help to develop and improve sentencing theory and jurisprudence.

7. As also noted, Morris argued that sentences would be more consistent and principled, and appellate review would be greatly facilitated, if trial courts were required to state reasons for their sentences.

8. Morris opposed all mandatory penalties and categoric exclusions from probation eligibility, whether by statute or strict, legally binding guidelines. Despite his career-long concerns about sentencing disparity, he believed that judges must retain substantial discretion to consider case-specific facts and circumstances.

9. In his 1990 book with Michael Tonry,5 Morris built upon his earlier advocacy of noncustodial sanctions. That book explored and urged courts to employ a wide range of intermediate sanctions less intrusive than full-time incarceration but more intrusive than traditional probation. In order to give courts guidance and encourage wider use of such sanctions, while still promoting sentencing uniformity, Morris and Tonry proposed the concepts of interchangeable sanctions and equivalency scales (e.g., one day of home detention equals eight hours of community service). Judges would first identify the primary sentencing purposes applicable to the case and then select the type of sanction or sanctions best suited to achieving those purposes, using the equivalency scales to ensure that equally culpable offenders receive roughly similar sanction severity. 
10. Morris supported sentencing guidelines reforms provided that they retained substantial judicial discretion, strongly promoted the use of intermediate sanctions, included appellate review, and required trial courts to state reasons for their sentences. Morris also appeared to recognize the value of having such guidelines developed and monitored by a sentencing commission with some independence from the legislature, to at least partially insulate sentencing policy, and the determination of specific guidelines sentences, from short-term political pressures. Such insulation is especially important when the recommended guideline sentence is "real time," not subject to broad parole-release discretion.

Morris's sentencing model is comprehensive, thoughtful, and well-balanced, but it has also had critics. Andrew von Hirsch has repeatedly questioned how "limiting" Morris's model actually is-how wide is the "not undeserved" sentencing range ${ }^{6}$ Would traditional indeterminate sentencing systems, with their very high statutory maximum terms and specified minimum times to serve before parole, be consistent with the model? If so, what has been added? If not, how much further must the ranges be narrowed? To some extent Morris resolved this ambiguity in his later writings, endorsing sentencing guidelines under the conditions summarized above. ${ }^{7}$ But American guidelines systems vary quite a bit in their range widths, departure standards, and degree of legal binding force. ${ }^{8}$ Morris would probably reply that such diversity is a good thing-specific sentencing structures, and the precise balance struck between rule and discretion, must ultimately be decided by each jurisdiction, based on its particular history and current circumstances.

\section{Morris's Model in Practice-Limiting Retributivism under the Minnesota Guidelines}

The Minnesota Sentencing Guidelines, in effect since 1980 , were said to be based on a theory of "modified just deserts" 9 in which retribution is the "primary" sentencing goal. ${ }^{\circ}$ The Sentencing Commission clearly based its offense rankings and approved departure standards on desert; the "modified" part of the model seems to refer to the substantial weight the Commission gave to prior record and resource management (staying within projected prison capacity) in its recommended Guidelines prison durations and dispositions (executed versus suspended prison terms).

The Commission did not cite Morris's writings in any of its official reports, and I have not found any other evidence that his writings directly influenced the Commission's work. But as I have explained in more detail elsewhere," the system designed by the Commission bore a striking resemblance to Morris's model. And as that system evolved over time, most of the changes made by the Commission or by interpretive case law brought the system even closer to his model. Similarly, the Minnesota legislature did not endorse or appear to have been directly influenced by Morris's ideas, either when it enacted the 1978 Guidelines-enabling legislation or when it passed later sentencing and Guidelines-related statutes. But the 1978 act did appear to contemplate that Guidelines sentencing would be a hybrid system, reflecting all of the traditional purposes of sentencing while limiting case-specific discretion. Later statutes have tended to reaffirm the importance of crime-control goals and the application of case-specific discretion-thus making the system even more of a "modified" desert hybrid.

\section{A. Elements of Morris's Model in Minnesota's Guidelines, Case Law, and Statutes}

The legislature's implicit hybrid approach, combined with the Commission's "modified just deserts" model and refined over time by changes in the guidelines, interpretive case law, and further sentencing legislation, has produced an innovative sentencing structure that incorporates almost all of the key elements of Morris's model, described above.

\section{Sentences May Fall within a Substantial Range of} Deserved Penalties For the great majority of offenders ( 70 to 80 percent, depending on the year) the Guidelines recommend a suspended (stayed) prison term. The effective sentencing range in these cases is broad-with rare exceptions there are no required or recommended probation conditions; judges have discretion to impose almost any combination of conditions (which may include a jail term of up to one year) or no conditions. The top of the effective range is set by the recommended prison term (currently twelve to forty-eight months, depending on the grid cell) applicable when judges revoke probation, or initially depart and impose an executed prison term.

As for the 20 to 30 percent of offenders with recommended executed prison terms, the range of penalties is also quite broad. Although the sentence ranges for these offenders were originally very narrow, they have been widened in recent years, especially in response to the Supreme Court's Blakely decision. In 1980 the range in most cells extended 4 to 7 percent above and below the midpoint of the cell, and no cell ranges overlapped; today, all cell ranges extend 15 percent below and 20 percent above the midpoint, and the ranges overlap considerably. ${ }^{2}$ Even under the narrow ranges formerly in effect, the effective sentencing range was much broader. Charging and plea bargaining are not regulated by the Guidelines or statutes, so it is likely that charge and plea concessions often yield penalties less severe than the lower end of the range for the offender's conviction offense. The probable effects of plea bargaining can be seen in the strong asymmetry of durational and especially dispositional departure rates-downward departures have always been much more frequent than upward departures. ${ }^{3}$ Moreover, the available "real offense" data suggests that many other sentences, even if formally not departures, are below the range provided for the more serious offense(s) of which 
the offender would have been convicted but for charging and plea bargaining concessions. ${ }^{14}$

Notwithstanding the wide ranges available to Minnesota sentencing judges, desert sets a firm upper limit on sanction severity-upward durational departures from recommended stayed and executed prison terms must be based on aggravating offense circumstances, not dangerousness, need for general deterrence, or other non-desert-based considerations. ${ }^{15}$

\section{Nondesert Purposes and Parsimony Apply within} These Substantial Desert Ranges When sentencing within the cell ranges for presumptive-prison cases, and in setting conditions of probation, the Guidelines permit judges to consider all of the traditional purposes of punishment. The Guidelines also expressly adopt the principle of parsimony-judges should impose the least restrictive sanction that will achieve the purposes of the sentence. This principle applies both with respect to the use of custodial sanctions (Minn. Guidelines $\ I(3))$ and in determining probation conditions (id. \III.A.2).

Guidelines provisions defining allowable grounds for departure suggest a focus on the offender's deserts. But interpretive case law decided in the early 1980 s recognized that courts may also depart dispositionally (but not durationally) upon a finding of the offender's particular amenability or unamenability to probation. The former permits downward departure (probation, instead of the recommended prison term); the latter permits upward departure (immediate execution of the recommended stayed prison term). As I have argued elsewhere, ${ }^{16}$ this case law is consistent with Morris's theory if we make the following assumptions: First, desert limits are asymmetric-upper limits are strict but the lower end of the desert range is a flexible limit, permitting downward amenability departures. Second, the duration of a recommended stayed prison term is a deserved penalty given the offender's conviction offense and prior record; thus, upward, unamenability departures do not exceed desert (and neither do probation revocations, even though they, too, are often based on nondesert considerations).

\section{The Imposition and Length of Prison Terms Rarely} Depends on Dangerousness Predictions Guidelines departure standards do not allow judges to enhance recommended prison terms based on findings of offender dangerousness. ${ }^{17}$ The Guidelines achieve such enhancements only by means of the offender's criminal history score-the kind of actuarial risk assessment that Morris favored. Offender risk assessments are arguably an implicit factor under the amenability case law described above, but such risk is not, by itself, a basis for dispositional or durational departure. A number of sentencing laws enacted since 1980 do allow judges to depart upward from the duration of recommended prison terms based on findings of offender dangerousness, but most of these laws are narrowly tailored and infrequently applied..$^{18}$

\section{The Imposition and Length of Prison Terms Is Not} Based on Rehabilitation Assessments Recommended Guidelines sentences and allowable departure grounds do not allow judges to consider the offender's need for extended, in-prison treatment, ${ }^{19}$ although, as noted above, particular amenability to probationary treatment is a grounds for granting probation instead of the recommended prison term (and all released offenders can be required to participate in appropriate treatment programs). Nor does an offender's progress in treatment affect how long he or she stays in prison; parole release discretion was abolished (except for life sentences), and prison terms may only be shortened via good-conduct credits of up to one-third off the maximum time to serve. Consistent with Morris's attack on coerced prison treatment tied to parole release, the 1978 Guidelines-enabling statute declared that all prison programs would become voluntary and that nonparticipation in such programs would not reduce good-conduct credit.

However, in 1993 the legislature backtracked, adopting an intermediate position: inmates may lose good-conduct credit not only for disciplinary infractions but also for refusal to participate in prison programs. The revised Minnesota approach goes further than Morris's stipulation that inmates should be encouraged to enter and stay in programs long enough to see if they liked them. Still, the award of program-participation credit seems to be an allor-nothing matter, release dates do not depend on an inmate's supposed progress toward rehabilitation.

\section{Sentences Are Enhanced Based on Prior Record}

Morris believed that it is appropriate to impose more severe sanctions on previously convicted offenders, not only because they deserve more punishment but also because prior record is the best predictor of the offender's risk of future crime. The Minnesota Guidelines give substantial weight to criminal history in the determination of recommended prison terms. Within grid rows, the presumptive prison duration for the highest criminal history category is on average twice as long as for the lowest category. Moreover, "prior" record under the Guidelines is defined as of the date of sentencing, which allows multiple current offenses to substantially enhance punishment even without consecutive sentencing. In addition, criminal history strongly influences Minnesota judges' decisions to depart down or up from recommended Guidelines dispositions (prison versus probation). ${ }^{20}$

Most desert theorists either reject prior record as a basis for sentence enhancements or would give this factor much less weight than it receives under the Guidelines. ${ }^{21}$ Morris clearly disagreed with the former view. But he might be troubled by the strong role that prior record plays in Minnesota sentencing, especially given the racially disparate impact of this sentencing factor. ${ }^{22}$

\section{All Sentences Are Subject to Appellate Review \\ Under the Guidelines, the prosecution and defense may}


both appeal from any sentence. In practice only about 1 percent of sentences are appealed (in part because the Supreme Court early on stated that it would rarely reverse nondeparture sentences, and because many sentences are mutually agreed to in plea bargaining). But such appeals have been frequent enough not only to enforce Guidelines policies but also to develop the kind of "common law of sentencing" that Morris strongly advocated.

7. Sentencing Courts Must State Reasons All departures from the Guidelines must be supported by a statement of reasons, on the record, showing that there are "substantial and compelling circumstances" which make the departure sentence more appropriate than the recommended Guidelines sentence. Morris probably would have gone further, requiring judges to give reasons for every sentence, not just departures. Admittedly, his views on this issue were initially developed in the context of indeterminate sentencing; under the Guidelines it can be argued that a nondeparture sentence is supported by Guidelines policy and requires no case-specific reasons. But stating reasons for not departing helps to ensure that no exceptional circumstances are overlooked and facilitates appellate review; such reasons should at least be required in cases where one or both parties have requested a departure.

\section{Sentencing Courts Retain Substantial Discretion} As noted above, the Guidelines give trial courts considerable discretion to tailor the sentence to the particular offense and offender. Judges have almost total discretion in choosing conditions of probation for the 70 to 80 percent of cases with a recommended nonprison sentence, and in the remaining (presumptive-prison) cases, grid cell ranges are now quite broad. Relatively few cases are subject to mandatory minimum penalties, and in many of these cases courts may sentence apart from the "mandatory" penalty by meeting the standard for Guidelines departure. ${ }^{23}$ In these and all other cases, "substantial and compelling reasons" are needed to depart, but courts often find that such reasons exist, particularly reasons to depart downward. In recent years about 30 percent of defendants facing a presumptive-prison sentence have received probation, and 25 to 40 percent of defendants sent to prison had a durational departure (more often down than up). These forms of remaining judicial discretion are in addition to the case-specific tailoring available through charging and plea bargaining, which are not regulated by the Guidelines.

\section{Courts Are Encouraged to Use Intermediate Sanc-} tions The Guidelines list and encourage judges to use a wide variety of probation conditions. Use of such intermediate sanctions is facilitated by the broad discretion courts retain, when choosing conditions of probation, and the substantial power they exercise to depart from recommended prison sentences. However, Minnesota could have done more to encourage the use of such sanctionsby providing, as some other states have done, guidance to trial courts in the choice among these sanctions, and state funding to the local court and correctional authorities who often lack the necessary facilities and staff. ${ }^{24}$

\section{Guidelines Are Developed and Monitored by an} Independent Sentencing Commission This was not originally Morris's idea (Judge Marvin Frankel is commonly credited with it), but Morris became a strong supporter of commission-based guidelines such as those in Minnesota.

Minnesota's experience over almost three decades shows the wisdom of the commission structure-insulating "real time" sentencing policy from short-term political pressures; allowing sentencing policy to be guided by detailed data collected and analyzed by expert staff and commission members representing the public and all parts of the criminal justice system; facilitating comprehensive policy making and priority setting (not ad hoc, crime-of-the-week legislation); and promoting a long-term perspective (not one driven by electoral or news cycles).

\section{B. Morris and the Minnesota Guidelines-Causation or Correlation?}

As noted earlier, I have found no evidence that Minnesota legislators, Sentencing Guidelines Commission members and staff, judges, or other sentencing policy makers were directly influenced by Norval Morris's sentencing theories. So how did Minnesota end up with a system so similar to his model? One possibility is that Morris's ideas strongly influenced other sentencing scholars and model rules, and that these people and rules, in turn, influenced many of the key actors who shaped the Minnesota Guidelines. There may also have been a sort of parallel evolution; Morris's methodology-the way in which he derived his theories and proposals-was similar to the way in which Minnesota policy makers derived the Guidelines.

A number of sentencing scholars directly contributed to the work of the Minnesota Commission when it was designing the Guidelines. (I was not one of them; my career as a sentencing scholar began when the initial Guidelines were proposed to the legislature, in January 1980.) One of the most frequent correspondents and contributors was Michael Tonry. As is well known, Tonry was a protégé of Norval Morris, and the two worked closely together from the mid-1970s until Morris's death in 2004. Still, I have found no concrete evidence that Tonry was promoting Morris's sentencing theory in his communications with the Minnesota Commission. Indeed, as indicated in Tonry's essay in this volume, it appears that even Morris himself was not promoting his theory in the "mock commission" project with which Morris and Tonry were involved in 1977 to 1978 . Nor is there evidence that other frequent advisors to the Minnesota Commission, such as Dan Freed and Andrew von Hirsch, were promoting Morris's ideas; indeed, von Hirsch strongly favored a 
more purely retributive approach, which the Commission rejected in favor of its Morrisonian, "modified just deserts" model.

Perhaps the strongest link I have found between Morris's ideas and the decisions of Minnesota sentencing reformers and policy makers is the second edition of the American Bar Association's sentencing standards, ${ }^{25}$ which obtained final approval in August of 1979-just as the Minnesota Commission's proposals were beginning to take shape. Most of the key elements of Morris's theory and what would become the Commission's model were present, including a generous sentencing range with firm upper desert limits on sanction severity (lower limits being more flexible, and based on not "depreciating" offense seriousness); an overarching principle of parsimony (“least restrictive alternative”); limits (albeit less than Morris would have wanted) on extended-term sentencing of dangerous offenders; for other offenders, recidivism risk to be based on verified present or past offending; allowing rehabilitative goals to be a basis for a probation, but not a basis to impose or extend a custodial sentence; cautious retention of parole release discretion, requiring "early" setting of the offender's proposed release date; two-way appellate review of sentences, to promote a common law of sentencing; statements of reasons for sentences; increased use of intermediate sanctions; a permanent sentencing commission to promulgate and oversee guidelines; and guidelines that incorporate intermediate sanctions and have only "modest" legal effect, leaving judges with a substantial amount of discretion. On some of these points, the Commentary to the standards explicitly stated that it was adopting Morris's views. ${ }^{26}$

Again, however, I have found no clear evidence that Minnesota sentencing reformers and policy makers actually based their decisions on the ABA standards. And of course, to some extent the causal arrow runs in the opposite direction-Morris continued to refine his theory after 1980 and came to endorse guidelines because they seemed to be well designed and working well in Minnesota and other early guidelines states.

As for the elements of Morris's model which he had identified before 1980 , perhaps the best (or most parsimonious) explanation for the adoption of these same elements in Minnesota is parallel evolution. But given the way in which Morris went about identifying and refining his principles-his jurisprudential methodology-it was no accident that sentencing reformers and other policy makers in a progressive, good-government state like Minnesota would independently discover the same principles. Morris was a reformer but also an empiricist and a realist. He first sought to find out how judges and practitioners think and act, so that his reforms might build on the accumulated wisdom of the past and avoid proposing highly unpopular or unworkable rules that would be ignored or circumvented in practice. Using this "from-the-ground-up," consensus-seeking approach, Morris identified fundamental and widely shared goals and values that must be accommodated if a new sentencing system is to flourish and survive. The practically minded people who crafted, implemented, and refined Minnesota's Guidelines used a similar approach and arrived at the same principles.

\section{Conclusion}

Although many features of the Minnesota Guidelines have counterparts in Morris's theory, Minnesota also pioneered a critical element that Morris did not foresee-the use of prison-population impact assessments to guide drafting and revision of guidelines rules and related sentencing statutes. Such assessments became administratively feasible and more accurate under Minnesota-style guideline sentencing, with its more predictable sentencing patterns, substantial sentencing database, and expert commission staff.

Prison impact assessments are especially important in guidelines systems that abolish broad parole-release discretion; prison overcrowding and rapid growth must then be controlled from the "front end." Such control also allows policy makers to comprehensively consider all types of crimes and set priorities in the use of limited correctional resources. These benefits have led most other guidelines states to implement resource-impact assessments; indeed, this became a major reason to adopt guidelines.

Although not foreseen by Morris, this feature of commission-based guidelines may very well be what makes sentencing parsimony actually work in practice, protecting systems like Minnesota's from the dreaded “Zimring eraser" - the strong tendency of elected policy makers to steadily escalate penalties which, in a determinate sentencing system, translates directly into more severe sentences imposed and served. ${ }^{27}$ Front-end impact assessments and priority setting also help promote greater proportionality across offense types.

In some respects Minnesota has not done as much as Morris would have liked. Many important decisions remain largely unregulated, including charging, plea bargaining, conditions of probation, revocation of probation and parole, and all misdemeanor sentencing decisions. Minnesota remains extremely parsimonious in its use of prison sentences but makes more frequent use of local jail terms than Morris would have liked-these are the kinds of cases (short custody terms, nonviolent offenders) for which intermediate sanctions are particularly appropriate and feasible. Minnesota has also backtracked on several of Morris's central principles, enacting numerous laws allowing "dangerous-offender" sentencing enhancements and/or traditional parole release discretion, and steadily escalating sex offender penalties with little regard for parsimony and the upper limits of desert. ${ }^{28}$ Despite these areas of disagreement and backsliding, however, Minnesota's sentencing system remains true to Morris's model in most respects.

What will the future bring? Given the many benefits of the Morris-Minnesota model, its endorsement in the ABA 
standards and the recent project to revise the Model Penal Code, ${ }^{29}$ and the proven ability of Minnesota-style guidelines to accommodate the added demands of Blakely $v$. Washington, $3^{30}$ there is reason to believe that more states will adopt this model. But will it survive in Minnesota and the other states with similar systems already in place? That will depend on whether these states continue to take a comprehensive, long-term, data-informed view of sentencing policy and never lose sight of what these reforms have accomplished and why they were adopted in the first place.

Even if the Morris-Minnesota model spreads and survives, will these systems be as well constructed and maintained as Minnesota's seems to have been? That will depend, to a large extent, on the people working in these systems. Norval Morris and Dan Freed can certainly be described as sentencing policy giants. But Minnesota's success depended on the vision, talent, and energy of its own, homegrown giants-commissioners like (chair) Jan Smaby and (member/Judge/Justice) Douglas Amdahl; dedicated staff like Dale Parent, Kay Knapp, and Debra Dailey. Other successful sentencing guidelines systems have likewise found, and continue to find, their own giants.

\section{Notes}

- I am very grateful to Marc Miller and Steve Chanenson for proposing and organizing the panel, to NASC for including the panel as part of its annual meeting, to the Stanford Crim. inal Justice Center for their support, and to the Federal Sentencing Reporter for its attention both to ideas and to the judges, lawyers, and scholars who offer them.

1 For further discussion of Morris's early and later writings on sentencing, see Richard S. Frase, Sentencing Principles in Theory and Practice, 22 CRIME \& Justice: A Review of RESEARCH (Michael Tonry, ed.) 363.433 (1997).

2 See generally id.

3 Norval Morris, Madness and the Criminal Law 192, 198 (Univ. of Chicago Press 1982).

4 Norval Morris, The Future of IMprisonment 60, 77.79 (Univ. of Chicago Press 1974)

5 Norval Morris \& Michael Tonry, Between Prison and Probation: Intermediate Punishments in a Rational Sentencing System (Oxford Univ. Press 1990).

6 Andrew von Hirsch, Utilitarian Sentencing Resuscitated: The American Bar Association's Second Report on Criminal Sentencing, 33 Rutgers L. Rev. 772, 785 (1981). For further discussion of the contrast between Morris's views and those of von Hirsch, see Frase, Sentencing Principles in Theory and Practice, supra, at 378.88 .

7 See generally, Limiting Retributivism, in THE FUTURE OF IMPRISON. MENT (Michael Tonry, ed.) 83.119 (Oxford Univ. Press, 2004).

8 For a summary and discussion of variations in American guidelines systems as of January 2005, see Richard S. Frase,
State Sentencing Guidelines: Diversity, Consensus, and Unresolved Policy Issues, in Symposium, Sentencing: What's at Stake for the States? 105 CouUmB. L. REv. 1 190-1232 (2005).

9 Minn. Sentencing Guidelines Comm., Report to the Legislature 9 (1980).

10 Minn. Sentencing Guidelines Comm., The Impact of the Minnesota Sentencing Guidelines: Three-Year Evaluation 10 (1984).

11 See generally Frase, Sentencing Principles in Theory and Practice, supra.

12 These and other Guidelines modifications made in response to Blakely are discussed in Richard S. Frase, Blakely in Min. nesota, Two Years Out: Guidelines Sentencing is Alive and Well, 4 Ohio State J. Crim. L. 73.94 (2006).

13 See Richard S. Frase, Sentencing Guidelines in Minnesota, 1978-2003, 32 Crime and Justice: A Review of ResearCH (Michael Tonry, ed.) 131, 172.73, 184, 191 (2005).

14 For discussion and examples of the higher "departure" rates that result if based on real.offense data, see Richard S. Frase, Implementing Commission-Based Sentencing Guidelines: The Lessons of the First Ten Years in Minnesota, 2 CornelL J. L. \& PuB. POL. 279, 299.303 (1993).

15 These and other cases interpreting the Guidelines are dis. cussed in Frase, Sentencing Principles in Theory and Practice, supra, at 398-400.

16 ld. at $400-403$.

17 Id. at 398

18 See Frase, Sentencing Guidelines in Minnesota, supra, at 159 63,184 .

19 See Frase, Sentencing Principles in Theory and Practice, supra, at 398.

20 See Frase, Implementing Commission-Based Sentencing Guidelines, supra, at 308-16.

21 Frase, State Sentencing Guidelines, supra, at 1212-13.

22 In 2005, for example, the average black criminal history score was 2.20 (out of 6 ), whereas the average score for whites was 1.48. For further discussion of this and other dimensions of racial disparity in Minnesota criminal justice, see Richard S. Frase, What Explains Persistent Racial Disproportionality in Minnesota's Prison and Jail Populations? 38 Crime and Justice: A Review of Research (Michael Tonry, ed.) (forthcoming 2009).

23 See Frase, Sentencing Guidelines in Minnesota, supra, at 158 59.

24 See Frase, State Sentencing Guidelines, supra, at 1225.26.

25 Amer. Bar Association, Sentencing Alternatives and Procedures, in 3 Standardos for Criminal Justice ch. 18 (2d ed. 1980).

26 Id. Standard 18.3.2(a)(1) and Commentary.

27 Franklin E. Zimring, Making the Punishment fit the Crime: A Consumer's Guide to Sentencing Reform, 6 HASTINGS CENTER REPORT 13 (1976).

28 For further discussion, see Frase, Sentencing Guidelines in Minnesota, supra, at 159.63, and Richard S. Frase, The Minnesota Sentencing Guidelines, in Penal Populism, Sentencing Councils and Sentencing Policy (Arie Freiberg \& Karen Gelb, eds.) (Willan Publishing 2008).

29 See American Law Institute, Model Penal Code: Sentencing, Tentative Draft No. 1 (2007), Sec. 1.02(2), Comment.

30 For further discussion, see Frase, Blakely in Minnesota, supra. 